\title{
БИОЛОТИЧЕСRИЕ HAУRИ
}

UDC: $574.24: 581.543$

GRNTI: 34.29

\section{ECOLOGICAL - PHYSIOLOGICAL CHARACTERISTICS OF FODDER PLANTS USED TO PREVENT DESERTIFICATION IN THE CHUST-PAP ADYRS OF THE FERGHANA VALLEY}

\author{
Imomov Otabek Normirzoyevich, \\ Namangan State University, Uychi str, 316, \\ Namangan, 160100, Uzbekistan \\ Rakhimova Turakhon Uzakovna, \\ National University of Uzbekistan named after Mirzo Ulugbek, \\ University str, 4, Tashkent, 100174, Uzbekistan \\ Mirzaev Saidmakhmud, \\ Namangan State University, Uychi str, 316, \\ Namangan, 160100, Uzbekistan \\ DOI: $10.31618 /$ ESU.2413-9335.2020.5.75.864
}

ABSTRACT

Adyrs of Chust-Pap, located in the north-west of the Ferghana Valley of the Republic of Uzbekistan, the process of desertification due to anthropogenic influences has been observed over the past 35-40 years. This process was confirmed by scientists, and evidence was provided. The aim of this study was to analyze the threeyear data on the parameters of the water regime in the conditions of rainfed cultivation of such local plants as Salsola orientalis S. G. Gmel., Kochia prostrata (L) Schrad. subsp. grisea prat. Subsp. nov., Krascheninnikovia ewersmanniana (Stschegl. ex Losinsk.) Grubov., Artemisia sogdiana Bge., used in the restoration of plant communities. A scientific basis has been created for the propagation of species to prevent desertification, that adapted to the region and common in natural ecosystems.

Keywords: Salsola orientalis, Kochia prostrata, Krascheninnikovia ewersmanniana, Artemisia sogdiana, water regime, desertification.

Introduction. At present, the negative impact of anthropogenic factors on nature, climate change, increasing air temperature, increasing desertification due to the irrational use of nature, as well as the protection and restoration of degraded, depleted ecosystems, is of increasing importance. In Central Asia over the past 30 years, global warming has been higher than the global average, agricultural land has declined by $50 \%$ due to growing desertification, and ecosystems have become unstable [20].

Chust - Pap adyrs (Adyrs - piedmont semideserts) in the north-west of the Ferghana Valley, stretching from the south-west to the north-east, officially part of the Namangan region of the Republic of Uzbekistan. It is bounded in the north and west by the Chatkal-Kurama ridges of the mountains of the Western Tien Shan, the eastern part of which is connected with the Namangan adyrs, and the southern part extends to the Syr Darya river. The northern and southern coordinates occupy $-41^{\circ} 00^{\prime}$ and $40^{\circ} 45^{\prime}$ north latitude, and the western and eastern edges $-70^{\circ} 25^{\prime}$ and $71^{\circ} 22^{\prime}$ east longitude. The part highlighted in red in Figure 1 is a section of Chust-Pap adyrs. Altitude 4501500 meters [11] as described by K.Z. Zakirova, this is the Adyr region [21]. The total area of the Namangan region used as natural pasture is 153.1 thousand ha [10], of which about 60 thousand ha are Adyrs of Chust-Pap. It is used by local farmers and residents as autumn, winter and spring pastures.

The climate of these adyrs is close to the desert, the average annual rainfall is $195-200 \mathrm{~mm}$, the longterm temperature is from +13 to $+15^{\circ} \mathrm{C}$, the soil is gravel-rocky, dark gray.

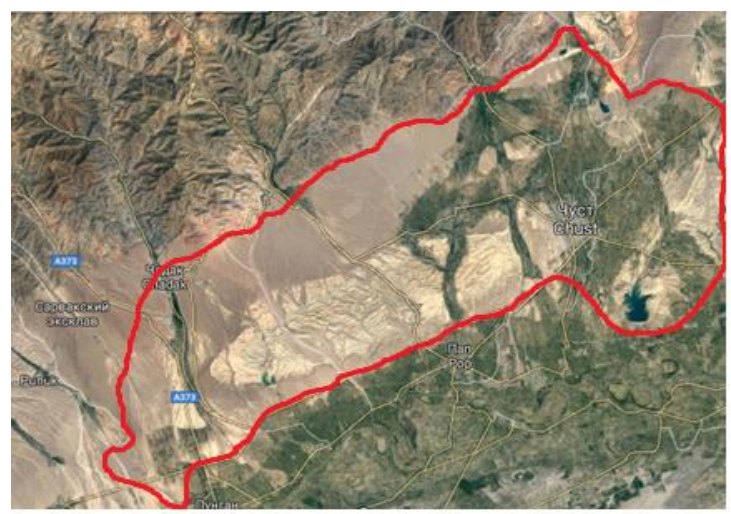

Figure 1. Chust-Pap adyrs 
An increase in soil erosion on Chust-Pap adyrs was revealed [15]. The increase in global air temperature was also analyzed in the adyrs regions of the Ferghana Valley, where the average air temperature was $12.9^{\circ} \mathrm{C}$ in $1924-1977$ and $14.75^{\circ} \mathrm{C}$ in $2006-2015$ [7], i.e. $1.85^{\circ} \mathrm{C}$ higher.

According to the plants' botanical and geographical zoning of academician K.Sh. Tojibaev in Uzbekistan, Chust-Pap adyrs belong to the Chorkesar district of the Western Tien Shan region of the Central Asian mountain Province [16]. According to studies conducted on these adyrs in 1970-1980, 300 species of plants belonging to 169 genus and 40 families were recorded [19]. However, over the next several decades, overgrazing, over-harvesting of medicinal plants, as well as technogenic and other anthropogenic impacts have led to a reduction in vegetation in the region. According to recent data, the vegetation of these adyrs has been greatly degraded [16]. In recent years here have been studied the current state of monocotyledonous geophyte plants [9], rare and endangered plants included in the Red Book of the Republic of Uzbekistan, and their new habitats [17], anthropogenic transformation of the vegetation cover [2]. According to G.A. Ibragimova, the vegetation cover of the Pap adyrs changed on average by $25-50 \%$, and the vegetation cover of the Chust adyrs changed by $50-75 \%$.

The bioecological characteristics of the species have been studied by many scientists with the goal of restoring pastures and communities with fodder plants in Central Asia. In the northern part of the Ferghana Valley, in the last quarter of the XX century, mainly on the Chartak Adyrs, the bioecology of fodder plants and the peculiarities of adaptation were studied $[18 ; 3 ; 14]$. The soil of the Chartak adyrs differs from the ChustPap adyrs in its relative fertility and high rainfall. The bioecology of the fodder plants that we have chosen in the adyrs of Chust-Pap has not been studied.

The aim of our study was to study the characteristics of adaptation to the region, in particular, the parameters of the water regime and the relationship between them by planting selected objects on Adyr Chust in dry conditions.

\section{Materials and methods}

The objects of study were Salsola orientalis S. G. Gmel., Kochia prostrata (L) Schrad, subsp.grisea Prat. Subsp. nov., Krascheninnikovia ewersmanniana (Stschegl. ex Losinsk.) Grubov., Artemisia sogdiana Bge. There are the following reasons why these species were chosen as the object of study: Artemisia sogdiana Bge. was edificator in this region [19], the plant is drought tolerant, belongs to the ecological group of chamephites, shrubs and teriohemoxerophytes (in summer it conducts summer dormancy) [14]. When a species that is an edifier is restored, it creates the conditions for the restoration of other species in the plant community. Salsola orientalis S.G. Gmel resistant to drought, belongs to the ecological group of chamephites, shrubs and hyperxerophytes. Subspecies Kochia prostrata (L) Schrad, subsp. grisea prat. Subsp. nov. and the species Krascheninnikovia ewersmanniana (Stschegl. ex Losinsk.) Grubov. drought tolerant, belongs to the ecological group of chamephites, shrubs and euxerophytes [14]. All species grew earlier in this area, they were fodder plants for finely horned and as a result of consumption in large quantities by livestock until the seeds ripen and shed, not completing the growing season in Chust-Pap adyrs, the number of plant bushes decreased from the 1970s and 1980s.

The water content in the leaves of plants was determined by the gravitational method on a torsion balance, the transpiration rate by L.A. Ivanova (1950), water retention capacity of plants to according to the method of A.A. Nichiporovich (1926), determination of the osmotic pressure of the juice of plant cell leaves according to N.A. Gusev (1960), and soil moisture was determined by the method of A.A. Rode (1969). The results were statistically analyzed. In determining the relationship between the parameters of the water regime, the correlation coefficient of K. Pearson was used.

The experiments were carried out in 2009-2011 on the pasture of the farm "Jahongir-Varzik", located in the Chust adyrs, $5 \mathrm{~km}$ east of the town of Chust. Currently, on the farm "Dehkan Sharof" located on this Adyr, it has been created a seed-growing plot.

\section{Results and discussion}

Water exchange of plants depends on such factors as daily and seasonal climatic factors: precipitation, air temperature, soil moisture. Since the plants were planted in the fall - at the end of November, the climatic diagram of climatic data observed on Chust-Pap adyr during the years when the experimental experiments were carried out was obtained from November to October, from May to September, when the main vegetation period of the plants is a small amount of rainfall, weather warm, dry climate observed (Figure $2)$. 


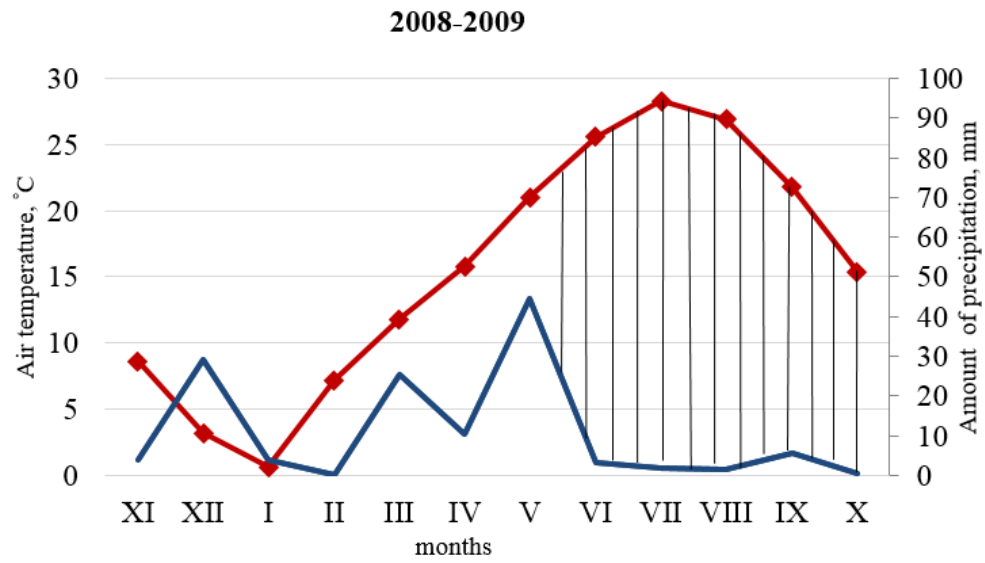

2009-2010

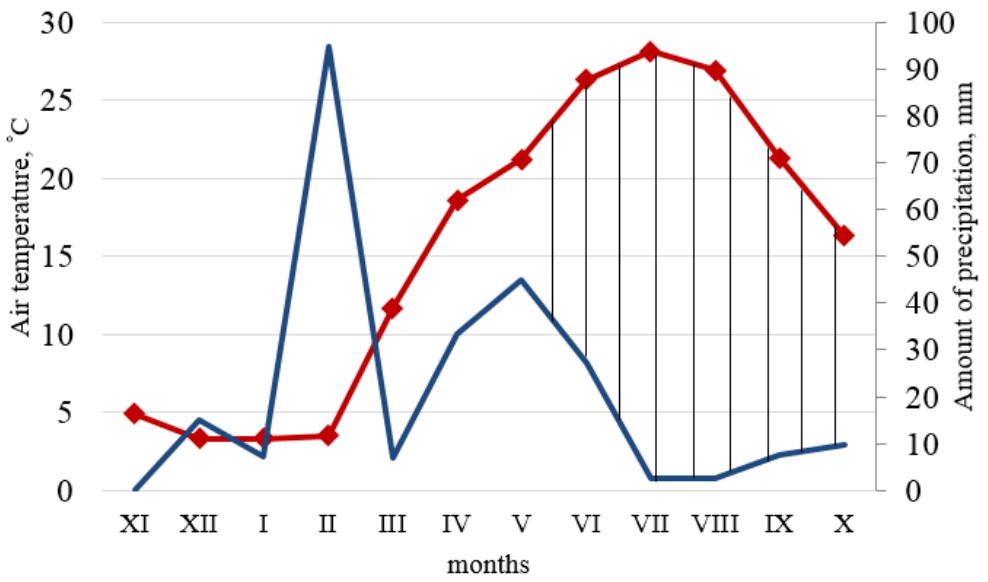

2010-2011

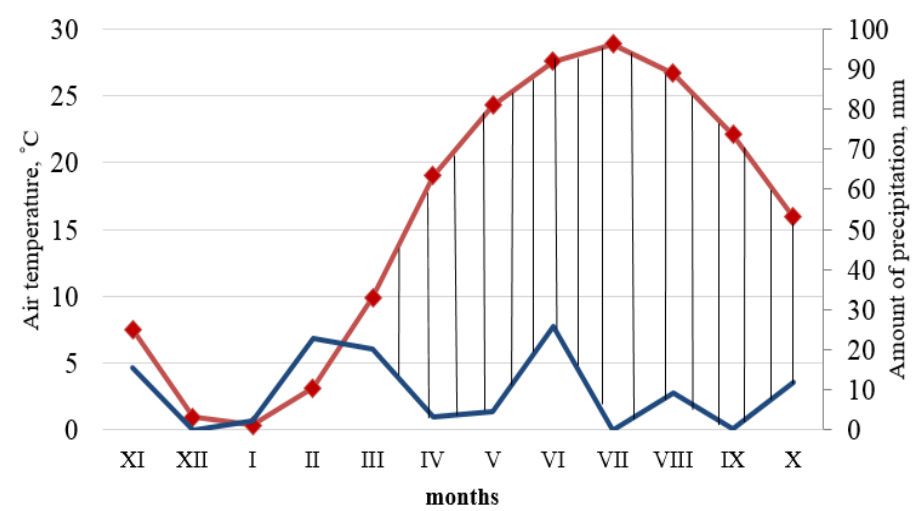

$\longrightarrow$ Air temperature, ${ }^{\circ} \mathrm{C} \longrightarrow$ Amount of precipitation, $\mathrm{mm} \longrightarrow$ Dry period

Figure 2. Climatic diagrams.

The amount of precipitation was $129.8 \mathrm{~mm}$ in $1.5 \mathrm{~m}$, soil moisture was studied from March to August 2008-2009; $251.9 \mathrm{~mm}$ in 2009-2010 and $114.5 \mathrm{~mm}$ in 2010-2011, mainly observed in autumn, winter and early spring. Since plant roots grow to a depth of 1 to to a depth of $150 \mathrm{~cm}$ (Table). There is also a decrease in soil moisture during the season from spring to late summer.

The change in soil moisture in the experimental plot (\%)

\begin{tabular}{|c|c|c|c|c|c|c|}
\hline \multicolumn{7}{|c|}{2009} \\
\hline Soil layers, (cm) & March & April & May & June & July & August \\
\hline $0-50$ & 5.9 & 4.67 & 6.18 & 1.38 & 0.95 & 1.11 \\
\hline $50-100$ & - & 3.26 & 2.99 & 2.89 & 1.58 & 1.68 \\
\hline $100-150$ & - & - & 3.63 & 3.16 & 2.55 & 3.07 \\
\hline Average & 5.9 & 3.96 & 4.26 & 2.47 & 1.69 & 1.95 \\
\hline \multicolumn{7}{|l|}{2010} \\
\hline $0-50$ & 7.52 & 8.38 & 3.41 & 1.61 & 1.1 & 1.19 \\
\hline
\end{tabular}




\begin{tabular}{|c|c|c|c|c|c|c|}
\hline $50-100$ & 3.22 & 3.44 & 2.75 & 1.92 & 1.81 & 1.62 \\
\hline $100-150$ & 3.52 & 3.21 & 3.78 & 3.09 & 2.81 & 2.96 \\
\hline Average & 4.75 & 5.01 & 3.31 & 2.20 & 1.90 & 1.92 \\
\hline \multicolumn{7}{|c|}{2011} \\
\hline $0-50$ & 4.82 & 3.44 & 2.89 & 1.4 & 1.14 & 1.15 \\
\hline $50-100$ & 3.11 & 3.06 & 3.3 & 2.87 & 1.62 & 1.69 \\
\hline $100-150$ & 3.49 & 3.45 & 3.3 & 3.14 & 2.56 & 3.08 \\
\hline Average & 3.80 & 3.31 & 3.16 & 2.47 & 1.77 & 1.97 \\
\hline
\end{tabular}

At different stages of the development of plant ontogenesis, morphological, bioecological, seed germination, changes in some parameters of the water regime during the season and day were studied $[4 ; 5]$. Below are the results of the three-year results of determining the parameters of the water regime based on statistical analysis and their discussion:

Seasonal changes in the parameters of the water regime of Salsola orientalis are shown in Figure 3, the water content in the leaves of the plant is high among the studied species and ranges from 82.54 to $49.78 \%$, and the three-year average is $63.49 \%$. The plant maintained its high rates in May, June, July and August. The water content does not change dramatically throughout the day. The transpiration rate is lower than in other species, $265.11-452.33 \mathrm{mg} / \mathrm{g} / \mathrm{hr}$, the three-year average is $362.51 \mathrm{mg} / \mathrm{g} / \mathrm{hr}$. During high season temperatures, transpiration decreased. This does not change dramatically throughout the day and season. This process ensures that the plant does not lose much water. The osmotic pressure of the juice of plant leaves increases from spring to summers' months July and in August. According to the results of the three-year period, 4.6 - $25.6 \mathrm{~atm}$. an average of $14.7 \mathrm{~atm}$. for three years The water retention capacity of the plant is also higher than that of other species. In June and July, the water retention capacity decreases at high temperatures. The water retention capacity was 74.26$91.26 \%$ for 3 years and $84.18 \%$ on average for three years.

The water regime of the Kochia prostrata plant is variable compared to Salsola orientalis (Figure 2), the water content in the leaves is lower than the previous plant during the season $(82.35-41.1 \%)$, the three-year average is $56.71 \%$. From spring to summer, it plummeted. During the summer months, when the temperature rises significantly, the water content decreases significantly. The transpiration rate is higher than that of Salsola orientalis, and decreases from spring to summer throughout the season. During the summer months, daily transpiration is low and conserves more water. Within three years, it varied within the range of $183.57-810.31 \mathrm{mg} / \mathrm{g} / \mathrm{hr}$ and on average $472.84 \mathrm{mg} / \mathrm{g} / \mathrm{hr}$ were recorded. When the temperature rises during the day (01:00 - 03:00 pm), transpiration rises with a difference of $200-700$ $\mathrm{mg} / \mathrm{g} / \mathrm{hr}$. The osmotic pressure of the juice of the leaf cells of the plant is higher than that of Salsola orientalis, 5.4 - $33.4 \mathrm{~atm}$. and the three-year average is $19.34 \mathrm{~atm}$. During the season, it gradually increased from April to July. Change during the day is 3 to 9 atm.p. The water retention capacity increased from April to July and August. According to the results of the three-year period, $68.66-87.33 \%$, an average of $79.53 \%$.

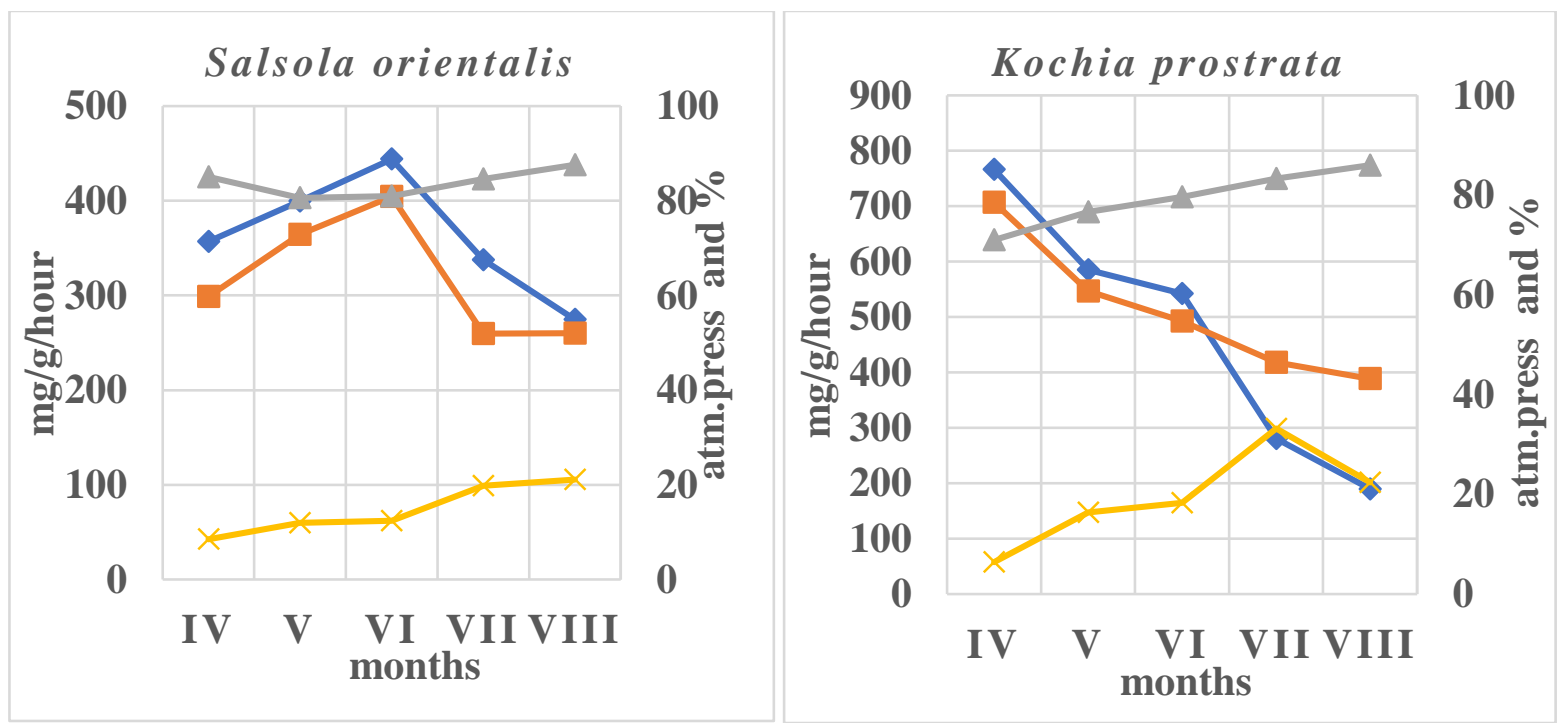




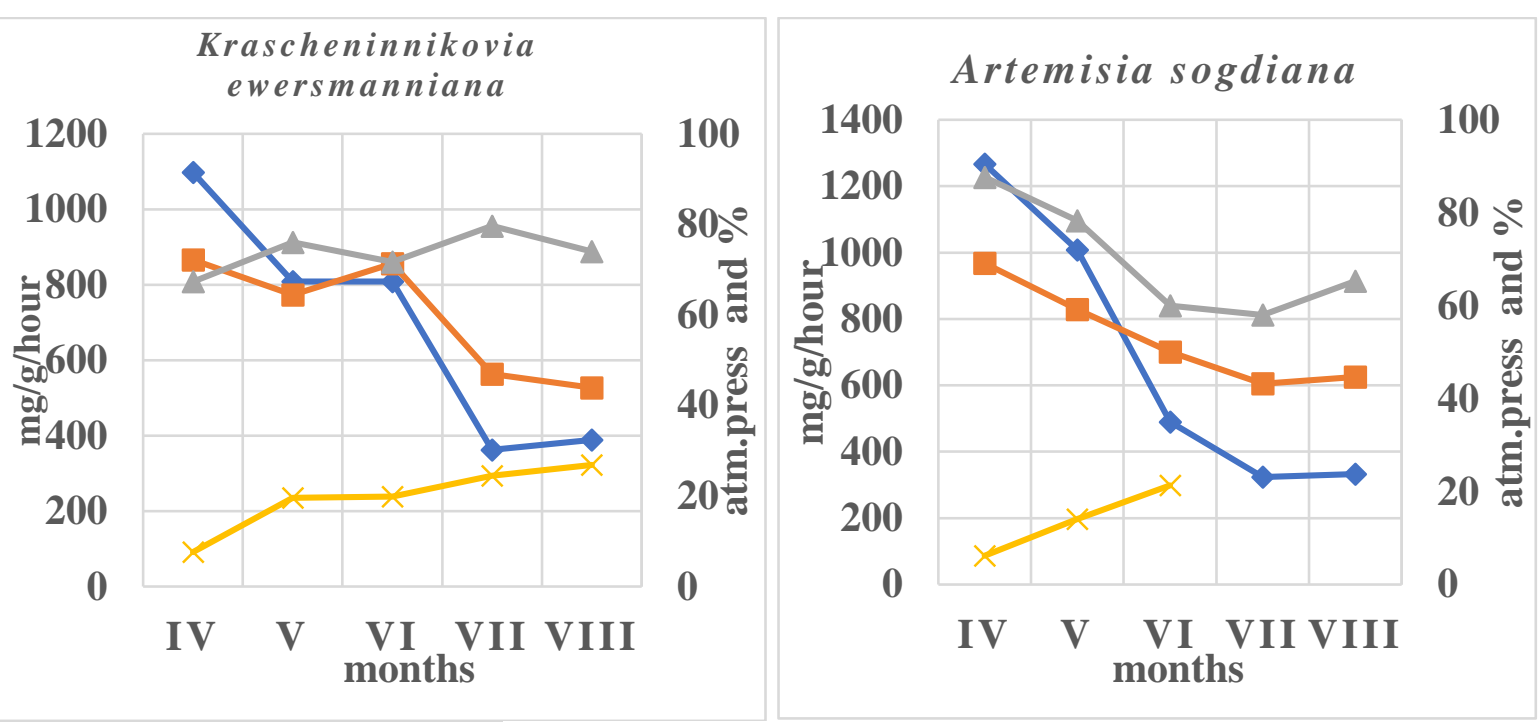

$$
\begin{aligned}
& \longrightarrow \text { The transpiration rate, } \mathrm{mg} / \mathrm{g} / \mathrm{hour} \\
& - \text {-Water content, \% } \\
& \leftarrow \text { Water retention capacity, \% } \\
& * \text { Osmotic pressure, atm. }
\end{aligned}
$$

Figure 3. The results of three-year parameters of the water regime of plants, the average seasonal change

Although the transpiration rate of Krascheninnikovia ewersmanniana is higher than that of Kochia prostrata (Figure 3), but it was found that the water content in the leaves of the plants is higher in May and June, but lower than that of Salsola orientalis. The three-year rate was $75.04-43.5 \%$ and averaged $59.75 \%$. The daily change in the water content is much stronger in June and July, when the air temperature rises, decreased by $18-24 \%$ compared with the morning indicator. The transpiration rate is higher than that of Kochia prostrata and significantly decreases from April to July. According to the results of the three-year period, $355.46-1111.05 \mathrm{mg} / \mathrm{g} / \mathrm{hr}$ and an average of $692.95 \mathrm{mg} / \mathrm{g} / \mathrm{hr}$. Daily transpiration also changes dramatically, daytime air temperature rises to a maximum, compared with the morning indicator differs by $200-600 \mathrm{mg} / \mathrm{g} / \mathrm{hr}$. The osmotic pressure of the juice of leaf plant cells according to the results of a threeyear period of $6.2-28.4 \mathrm{~atm}$. and an average of 19.65 atm. During the season, it grew from spring to summer. In April, May, June and August it is higher than that of Kochia prostrata, in July low results were recorded with a slight difference compared to Kochia prostrata. Change during the day is 3 to $10 \mathrm{~atm}$. The water retention capacity is $66.36-82.13 \%$, and on average $74.07 \%$ over three years, low in relation to Kochia prostrata, increasing during the season from April to July.

Artemisia sogdiana. The water content in this plant is low compared to other species, during the season it fell sharply from April to July. For three years, it was found from 82.35 to $41.1 \%$, an average of $56.71 \%$. It also fluctuates sharply during the day, in July and August, when the air temperature rose, it turned out that it fell by $15-20 \%$ compared with the morning indicator. The rate of transpiration of the plant based on three-year results is $306.2-1323 \mathrm{mg} / \mathrm{g} / \mathrm{hr}$, an average of $683.93 \mathrm{mg} / \mathrm{g} / \mathrm{hr}$. The transpiration rate fluctuates sharply during the season, higher than other species studied in April and May, and plummeted in June. It also fluctuates sharply during the day, in April and May, when the air temperature rises, it rose to 500 - $560 \mathrm{mg} / \mathrm{g}$ per hour compared with the morning indicators. The osmotic pressure of the juice of the leaves of plants is also higher than that of other studied species. For three years, from April to May and June, from 5 to $22 \mathrm{~atm}$. Because of the loss of the main leaves in the second half of June, it was impossible to determine the osmotic pressure of the juice of the leaf cells of this plant in July and August. In June, it fluctuates sharply during the day, reaching 9-13 atm. when the air temperature rises relative to the morning indicators. It turned out that the water retention capacity of the plant fluctuated sharply compared to other species, falling from a peak from April to July. This is due to the loss of leaves in June. According to threeyear data, the results were $91-54.23 \%$, and on average $70.07 \%$. The specific water regime of Artemisia sogdiana determines the adaptation of this plant to the region. The plant is in active vegetation in spring and autumn, although in summer it drops leaves on the lower parts of the stem.

Analysis of the relationship of water regime parameters. It is important to prove and analyze that there is a correlation between the identified parameters of the water regime in the study of plant adaptation and resistance to dry environments is of great importance for the reliability of the results, as well as for the correct assessment of the water regime of plants. If we collect together such basic parameters of the water regime of each plant as the transpiration rate, water content in the leaves of the plant, water retention capacity, osmotic pressure of the juice of the cell of the plants' leaves during the season, based on the reliability of the results obtained by identifying the correlation coefficients of the relationship between them, we can conclude about 
the features of the water regime, the adaptation of these plants to the arid region.

There is a positive relationship between the transpiration rate and water content, water retention capacity and the osmotic pressure of the Salsola orientalis plant. The transpiration rate of Salsola orientalis increased from April to June to $87.07 \mathrm{mg} / \mathrm{g}$, this is not a very sharp increase in transpiration intensity, and the amount of water also increased by $21.15 \%$, respectively. From June to August, both parameters began to decline. Water retention capacity and osmotic pressure also changed in the same direction in parallel during the season (Figure 3).

The inverse relationship between the transpiration rate and water retention capacity, transpiration rate and osmotic pressure, water content and water retention capacity, water content and osmotic pressure was determined. As can be seen from Figure 3, the water retention capacity has changed inversely with transpiration. The results of the correlation coefficient obtained over three years also confirm this. Positive correlations between positively correlated parameters and inverse correlation coefficients between inversely correlated parameters were determined (Figure 4).

In plants Kochia prostrata and Krascheninnikovia ewersmanniana, there is a positive relationship between the transpiration rate and water content, water retention capacity and osmotic pressure, the inverse relationship between the transpiration rate and water retention capacity, transpiration rate and osmotic pressure, water content and water retention capacity, water content and osmotic pressure (Figures 3; 4).

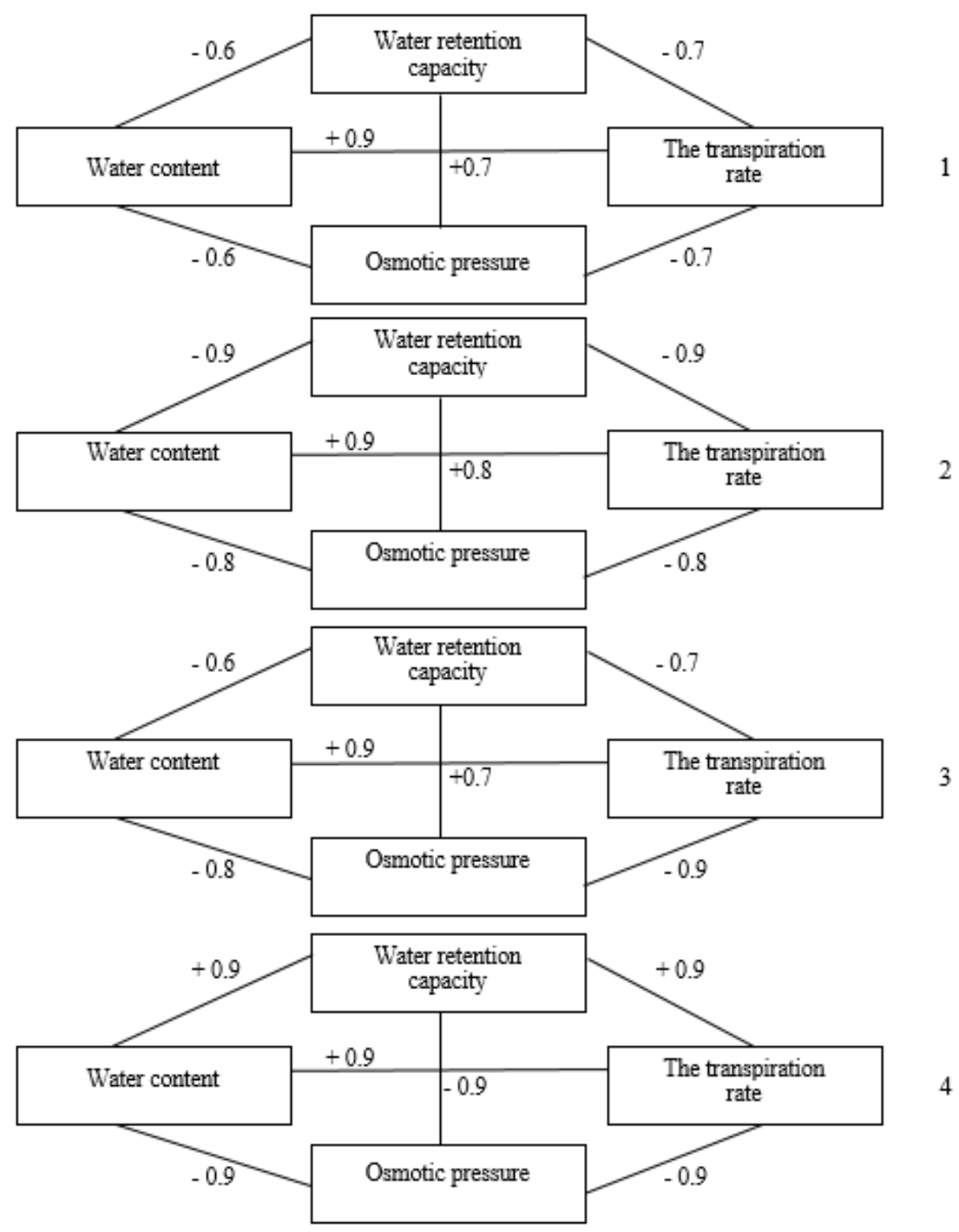

Figure 4. The dependence of the parameters of the water regime in plants

(Numbers are the correlation coefficients between the parameters

1. Salsola orientalis, 2. Kochia prostrata (L). Subsp. grisea 3. Krascheninnikovia ewersmanniana, 4. Artemisia sogdiana

This pattern of the relationship between the parameters of the water regime is determined not only in these plants, but also in all species belonging to the ecological group of hyperxerophytes and euxerophytes [14].
The water regime of the Artemisia sogdiana plant differs from the above species in a direct positive relationship between transpiration rate and water content, transpiration rate and water retention capacity, water content and water retention capacity, the inverse relationship between transpiration rate and osmotic 
pressure, water content and osmotic pressure, water retention capacity and osmotic pressure (Figures $3 ; 4$ ). Artemisia sogdiana violates the law of the inverse relationship between transpiration rate and water retention capacity. Such correlations between the parameters of the water regime were observed not only in the Artemisia sogdiana plant, but also in all plants belonging to the ecological group of theroiremoxerophytes [14].

\section{Conclusion}

The water regime of the plant Salsola orientalis is more stable than that of other species, and is well adapted to drought conditions. The parameters of the water regime of plants quickly adapt to high temperature and arid period of the season. The water content in assimilation tissues is high, the transpiration rate of the studied species is low, the osmotic pressure of the cell juice of plant leaves is stable, and the water retention capacity is high. These indicators of water regime prove that the plant is adapted to an arid environment.

The water regime of the plants Kochia prostrata and Krascheninnikovia ewersmanniana differ from that of Salsola orientalis, and these two plants maintain water balance by increasing the osmotic pressure of the juice of leaf cells. The plant Artemisia sogdiana maintains water balance due to the loss of leaves on the lower body and a sharp decrease in transpiration during high summer temperatures and drought. These features of the water regime of the studied plants prove that they are well adapted to the region and can be used to improve the ecosystem surface. Agrotechnical methods of plant propagation have been developed and recommended for practical use [6]. In all species aged two years and older, high yields are observed in late May and early June. The average annual yield was 1.52.0 t/ha in Salsola orientalis, 1.0-1.6 t/ha in Kochia prostrata, 1.0-1.7 t/ha in Krascheninnikovia ewersmanniana, 0,7-0,9 t/ha in Artemisia sogdiana. Using the results of our experiments, these plants can be used to restore natural ecosystems in drylands, to prevent desertification.

\section{References}

1. Gusev, N.A. Some Methods of Studying the Water Regime of Plants. Leningrad: Publishing House of the USSR Academy of Sciences, 1969. 38 p. (In Russian)

2. Ibrokhimova G. A. Anthropogenic transformation of plant in the northern part of the Fergana valley: PhD Thesis. Namangan. 2020. 33 p.

3. Iliakhunova S. Biology and aquatic regime of some species of annual saltwort's in the condition of Fergana adyrs: Abstr. ... Diss. Kand. Sci. Tashkent. 1993. P. 3-15.

4. Imomov O.N. Bioecological features perspective fodder plants in conditions Chust - Pap moors and optimization territory with their help. Scientific Bulletin of Namangan State University, 2019. 1: P. 72-81. (In Uzbek)

5. Imomov O.N. Biological and ecological features of Artemisia sogdiana Bge in the conditions of
Chust - Pap steppes in Ferghana valley. European science review, 2018. 3 - 4: P. $36-39$.

6. Imomov O.N. Ways to solve the desertification problem in Chust - Paps Adyrs. In: Biological diversity is the basis of sustainable development. Materials of the international scientificpractical conference. Groznyy: Chechen State Pedagogical University, 2019. P. 83-87. (In Russian)

7. Isagaliyev M.T., Yuldashev G.Yu. Change of climatic factors of soil-formation of mountain and submontane soils in Fergana valley. The Way of Science, 2016.9 (31): 24 p. (In Russian)

8. Ivanov L. A., Silina A.A., Tselniker Yu.L. On the method of rapid weighing to determine transpiration in natural condition. Botanical Journal, 1950. 2: P. 171-185. (In Russian)

9. Karimov F.I. Monocotyledonous geophytes of the Fergana valley: Abstr. ... Diss. Doct. Sci. Tashkent. 2016. 24 p.

10. Mahmudov M., Haydarov Q. Meadow farming. Toshkent: Doba, 2010. 17 p. (In Uzbek)

11. Mirzamahmudov O.T. The Estimation landscape - ecological condition of the Northern Ferghana adyrs: Abstr. ... Diss. Kand. Sci. Tashkent. 2007. P. $9-12$.

12. Naraliyeva N. M., Tojibaev K. Sh., Ibrohimova G. A., Nabiyeva D. B., Sidikjanov N. M. The Southern Territories of Chatkal Range - Key Botanical Territories of Fergana Valley. International Journal of Modern Botany, 2019. 9(1): P. 1-7.

13. Nichiporovich A.A. About water loss by cut parts of plants during wilting. The experience of agronomy of the South East, 1926. 3. (1): P. 76-92. (In Russian)

14. Rakhimova T.U. Ecology of plants of the Adyr zone of Uzbekistan. Tashkent: Universitet, 1997. P. 46-203. (In Russian)

15. Talanov Ye.A. Assessment of the degree of erosion dismemberment of basins and the main laws of mudflow hazard in mountainous regions. Bulletin of Tomsk State University, 2013. 375: P. 187-193. (In Russian)

16. Tojibaev K.Sh., Beshko N.Yu., Papov A.V. Botanical-geographical regionalization of Uzbekistan. Botanical journal, 2016. 101 (10): P. 1105-1132. (In Russian)

17. Tojibaev K.Sh., Naraliyeva N. M. New findings of rare and endemic Apiaceae species in Uzbekistan. Turczaninowia. Altay State University, 2012. 15 (4): P. 31-33. (In Russian)

18. Vernik R.S., Markova L.Ye., Rakhimova T.T. Biological features of fodder plants introduced into the culture. In: Ecological and biological basis for the creation of artificial pastures and hayfields on adyrs of the Ferghana Valley. Tashkent: Ukituvchi, 1977. 159 p. (In Russian)

19. Vernik R.S., Rakhimova T.T. Natural vegetation and pastures of adyrs of Namangan region. Tashkent: Fan, 1982. 10 p . (In Russian)

20. Yang YU., Yuanyue PI., Xiang YU., TA Zhijie., SUN Lingxiao., Markus DISSE., ZENG Fanjiang., LI Yaoming., CHEN Xi., YU Ruide. Climate change, water resources and sustainable development 
in the arid and semi-arid lands of Central Asia in the past 30 years. J. Arid Land, 2019. 11(1): 3.

21. Zakirov K. Z., Zakirov P. K. The typology of vegetation of the globe on the example of Central Asia. Tashkent: Fan, 1978. 56 p. (In Russian)
22.www.google.com/maps/place/Наманган/@4 $0.9903904,70.774702,75728 \mathrm{~m}$

УДК 574.584

ГРНТИ 34.33 .33

\title{
ОЦЕНКА ЧИСЛЕННОСТЕЙ НАТУРАЛИЗОВАВШИХСЯ ЧУЖЕРОДНЫХ ВИДОВ РЫБ В
} ПРИБРЕЖНОЙ МЕЛКОВОДНОЙ ЗОНЕ ЧЕБОКСАРСКОГО ВОДОХРАНИЛИЩА

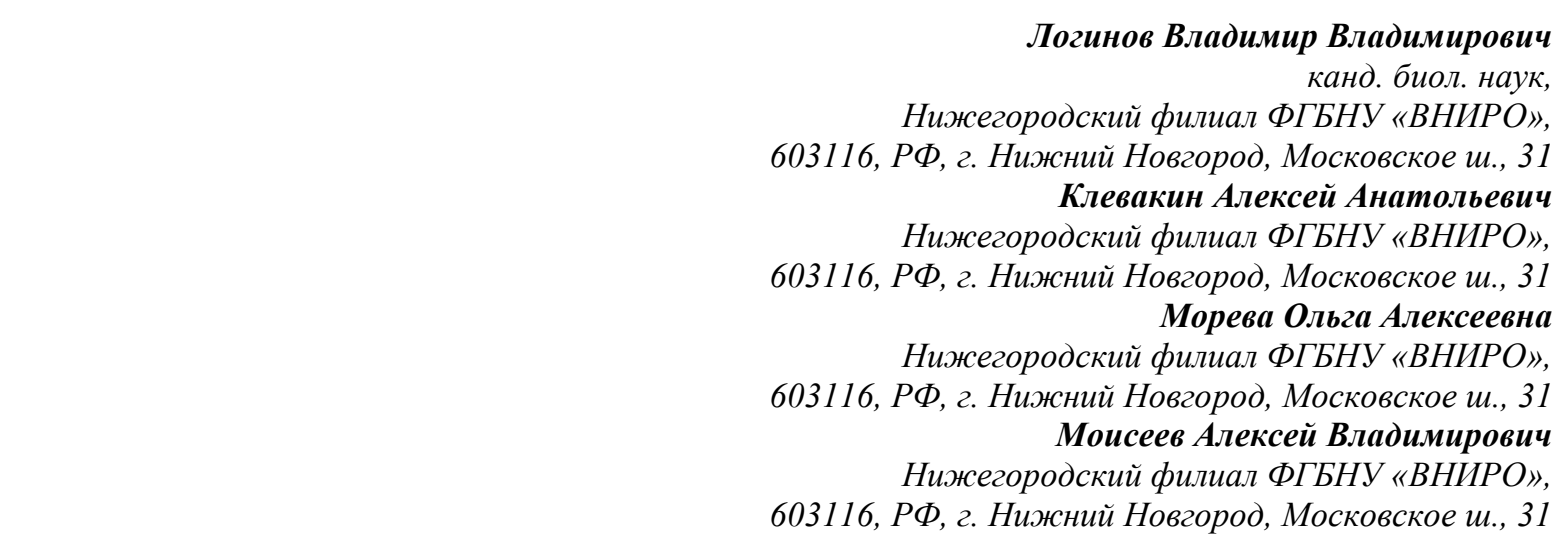

\section{ESTIMATION OF NUMBERS NATURALIZED INVASIVE FISH SPECIES IN THE SHALLOW WATERS OF THE CHEBOKSARY RESERVOIR}

\author{
Vladimir Loginov \\ candidate of Biological Sciences, \\ Nizhny Novgorod branch Russia Federal Research Institute of Fisheries and Oceanography, \\ 603116, Russia, Nizhny Novgorod, Moscow sh., 31 \\ Alexey Klevakin \\ Nizhny Novgorod branch Russia Federal Research Institute of Fisheries and Oceanography, \\ 603116, Russia, Nizhny Novgorod, Moscow sh., 31 \\ Olga Moreva \\ Nizhny Novgorod branch Russia Federal Research Institute of Fisheries and Oceanography, \\ 603116, Russia, Nizhny Novgorod, Moscow sh., 31 \\ Alexey Moiseev \\ Nizhny Novgorod branch Russia Federal Research Institute of Fisheries and Oceanography, \\ 603116, Russia, Nizhny Novgorod, Moscow sh., 31
}

\section{АННОТАЦИЯ}

Все 9 отмеченных на Чебоксарском водохранилище чужеродных видов рыб (Clupeonella cultriventris, Coregonus albula, Pungitius pungitius, Percottus glenii, Benthophilus stellatus, Neogobius fluviatilis, Neogobius iljini, Neogobius melanostomus, Proterorhinus marmoratus) полностью натурализовались и адаптировались к новым условиям среды. Это подтверждается увеличением их численности и встречаемости в прибрежной зоне Чебоксарского водохранилища в последние годы.

\section{ABSTRACT}

All 9 alien fish species noted on the Cheboksary Reservoir (Clupeonella cultriventris, Coregonus albula, Pungitius pungitius, Percottus glenii, Benthophilus stellatus, Neogobius fluviatilis, Neogobius iljini, Neogobius melanostomus, Proterorhinus marmoratus) completely naturalized and adapted to new environmental conditions. This is confirmed by the increase in their numbers and occurrence in the coastal zone of the Cheboksary reservoir in recent years.

Ключевые слова: чужеродные виды рыб, водохранилище, прибрежная мелководная зона, расширение ареала

Key words: alien fish species, reservoir, shallow coastal zone, expansion of the area

В настоящее время одной из глобальных экологических проблем является внедрение многочисленных чужеродных видов в пресноводные экосистемы. Натурализация чужеродных видов рыб в регионе вселения может негативно воздействовать на аборигенную ихтиофауну (хищничество, усиление конкуренции за кормовую базу, гибридизация, распространение 